\title{
SUSTAINABLE FOREST MANAGEMENT IN INDONESIA'S FOREST LAW (POLICY AND INSTITUTIONAL FRAMEWORK)
}

\author{
Sri Wahyuni \\ Fakultas Hukum, Universitas Islam Riau \\ E-mail: sri_wahyuni6969@ymail.com
}

\begin{abstract}
Indonesia Forest Law No. 41 Year 1999 in article 46 states: "Forest protection and nature conservation aim at keeping the forest, forest area and its environment, so that protection, conservation functions and productions, is achieved in an optimal and sustainable". With all issues that happen in Indonesia, so that Indonesia need to protect their forest and one of the way to do it is Sustainable Forest Management (SFM). SFM is the management of forest according to the principles of sustainable development. SFM uses very broad social, economic and environmental goals. All item of SFM are including also in the Indonesian Forest Law No. 41 year 1999. This paper would like to describe about Legal, Policy and Institutional framework to achieve the Sustainable Forest Management in Indonesia's Forest Law, with normative research.
\end{abstract}

Key words: forest, law, forest law, sustainable forest management

\begin{abstract}
Abstrak
Undang-Undang Pokok Kehutanan Indonesia Nomor 41 Tahun 1999 dalam pasal 46 menyatakan: "Perlindungan hutan alam dan tujuan konservasi adalah menjaga, kawasan hutan hutan dan lingkungannya, sehingga perlindungan fungsi konservasi dan produksi tercapai secara optimal dan berkelanjutan". Pengelolaan Hutan Berkelanjutan adalah pengelolaan hutan sesuai dengan prinsipprinsip pembangunan berkelanjutan. Untuk menjaga fungsi Perundang-undangan terhadap keberlanjutan hutan maka diperlukan Sustainable Forest Management/SFM (Pengelolaan Hutan Berkelanjutan), dimana SFM menggunakan tujuan sosial, ekonomi dan lingkungan yang sangat luas. Tulisan ini ingin menjelaskan tentang Hukum, Kebijakan dan kerangka kelembagaan untuk mencapai Pengelolaan Hutan Berkelanjutan di UU Kehutanan Indonesia, dengan penelitian normatif.
\end{abstract}

Kata kunci: hutan, hukum, hukum kehutanan, manajemen hutan berkelanjutan (SFM)

\section{Introduction}

International environmental law as a

whole is adapting to exogenous changes through an institutional process akin to natural selection in biological evolution. However, the adequacy of the direction and rate of adaptation for the purpose of safeguarding the integrity of Earth's life-support system is questioned. ${ }^{1}$ The forest sector plays a significant role in the accumulation of greenhouse gases (GHG) in the earth's atmosphere, and has a potential to play and even bigger through GHG emission reducti-

Rakhyun E Kim, Brendan Mackey, “International Environmental law as a complex adaptic system", Journal International Environmental Agreements, Politics, Law and Economics, Vol. 14, issue 1, 2014, pp 5-24 on and/or increasing carbon dioxide $(\mathrm{CO} 2) .{ }^{2} \mathrm{Fi}$ res have attracted interest and generated alarm since the early $1980 \mathrm{~s}$. This concern has been particularly evident in tropical forests of Southeast Asia and the Amazon, but disastrous fires in recent summers in Australia, Europe, and the United States have drawn worldwide attention. There remains a lack of clarity about 'fire problems', which has, at times, led to the adoption of policies that may have negative impacts on livelihoods, the environment, and the economy. Two 'simple' changes in the way fires

Willy R Markundi, "Global Climate Change Mitigation and Sustainable Forest Management-The Challenge Monitoring and Verification", Journal Mitigation and Adaptation Strategies for Global Change, Volume 2, Issue 2-3, Nov. 1997, pp 133-155 
are considered would significantly improve firerelated policies and initiatives, ${ }^{3}$ present relatively detailed accounts of biodiversity and the need to adopt conservation strategies to protect it. However, social and health impacts are only superficially addressed. The economic sustainability of the operation over multiple cycles is not demonstrated. ${ }^{4}$ First, fires should be seen as a component of land management processes, rather than as a' problem' to be prevented, suppressed, or mitigated; and second, not all fires are the same.

Following an economic crisis in Indonesia in 1998, forest depletion turned into severe deforestation due to massive illegal logging. An inability to enforce the laws, together with collective pressure from local communities during this crisis, marked the decline in the state's dominance and power with respect to forest governance. It is argued that in the specific case of environmental policy the initial assignment of rights will seriously affect the final allocation of resources. ${ }^{5}$ This situation highlighted the increasing pressure on the state to take the voices of other stakeholders into account and to change the existing ineffective governance. Pressure from the other stakeholders, including local communities, university scholars, and local Non-government Organizations (NGOs), led to the formation of a new social forestry program in $2001^{6}$ and population density is a positive predictor of "pro-environment" votes. $^{7}$

L. Tacconi, P.F. Moore, D.Karmowitz, "Fires in Tropical Forests-what really the problem? Lessons from Indonesia”, Journal Mitigation and Adaptation Strategies for Global Change, Vol. 12, Issue. 1, 2007, pp. 55-66,

4 Evaldice Eve, Fransisca A Arguelles, Phillip M. Fearnside, "How much do Brazils's Environmental Law work in practice? Environmental Impact Assessment and the case of the Itapiranga Private Sustainable Logging Plan", Journal Environmental Management, Vol. 26, Issue 3, 2000, pp. 251-267

5 Alessandra Arcuri, "A different Reason for "De-Coasing" Environmental Law and Economics", Journal European Journal of Law and Economics, Vol. 20, Issue 2, 2005, pp 225-246

6 Tri Lestari Djamhuri, "Community Participation in a social Forestry program in Central java, Indonesia: The Effect of incentive structure and social capital", Journal Agroforestry System, Vol. 74, Issue 1, 2008, pp 8396

7 William L Anderson, Daniel A Mizak, "Politics of Environmental Law: Political Ideology, Elitism or Urban-Ru-
Development in order to be sustainable essentially means that the very preconditions for human activity and welfare must be respected and protected. These conditions are based in the final instance on the earth's capacity to support life. This capacity is dependent on functioning natural systems. Human societies derive a wide array of important life-supporting and economic benefits from the ecosystems in which they exit ${ }^{8}$ and Complex ecological and social processes in tropical forests imply that observations on any single element of the system do not provide an adequate basis for sound forest management ${ }^{9}$.

At a minimum, the World Commission stated, sustainable development must not endanger the natural systems that support life on Earth, adding that were objective limits to what nature could bear. ${ }^{10}$ These systems are generated by a complex interplay of biological, geological, and chemical cycles driven by solar energy and operation across a wide range of spatial and temporal. Sustainable development is a term reflecting human, societal, and environmental values and in order to determine progress toward this goal; it is necessary to identify and define these values, and for governments or other institutions to establish the means to assess progress ${ }^{11}$.

A framework of criteria and indicators of sustainable forest management is being implemented in many countries as they move from the former goal of sustainable yields of fibre to the broader concept of sustainable development. These frameworks consist of a group of broad core values, criteria supported by a number of indicators or measures to assess status or

ral Interest?", Journal Public Choice, Vol. 129, Issue 12, 2006, pp 131-157

8 Brundtland Report, 1987, Report of the World Commission for Environment and Development, Our Common Future, Oxford: OUP

9 Herry Purnomo, Yurdi Yasmi, Ravi Prabhu, Linda Yuliani, Hari Priyadi, Jerome K Vanclay, "Collaborative modeling to support forest management: Qualitative system analysis at Lumut Mountain Indonesia", Journal Small Scale Forest Economics, Management and Policy, Vol. 2, Issue 2, 2003, pp 277-292

10 WCED, op.cit, pp. 44-5

11 J-Peter Hall, "Criteria and Indicators of Sustainable Forest Management", Journal Environmental and Assessment, Vol. 67, Issue 1-2, 2001, pp 109-119 
progress toward the realization of these values. There is a need to define the key elements or values to be sustained, and within each of these criteria, measurable indicators to demonstrate progress toward specific objectives. ${ }^{12}$

\section{The Terminology of Forest Management}

Sustainable Forest Management (SFM) embraces the view of the forest as yielding many different products and providing many different ecological services. Sustainable Forest Management will therefore produce an array of products and services which may or may not include timber. SFM therefore relates to the multiple use of the forest. To a forester, the term 'management' could relate to the management of resources, inventorying and yield calculation, and to silvicultural practice (e.g. climber cutting), so that, on some definitions, SFM is already embodied in good practice timber harvesting. Again, then, the terminology of SFM is not ideal but is retained here to convey the idea of multi-product uses and with a focus on the longer term. While environmental laws can provide a "back door" to protect traditional sites and practices, they are not made for this purpose, and, as such, require specific amendments to become more useful for indigenous practitioners. ${ }^{13}$

As noted above, the debate about appropriate forestry mixes two different aspects of sustainability: first, sustainable timber management (SFM) in which the focus is on a sustained yield of timber over long time periods; and second, sustainable forest management (SFM) in which the focus is on the many products and services of the forest sustained over long periods of time. In sustainable timber management, timber is extracted with regard to a continuous future supply of wood through investment in regeneration. SFM also tends to be

12 Anon, 1995, Criteria and Indicator for the Conservation and Sustainable Management of Temperate and Boreal Forests, The Montreal Process, Ottawa: Canadian Forest Service, p. 27

13 Beth Rose Middleton, “Just Another hoop to jump through? Using Environmental Law and Process to Protect Indigeneous Rights", Journal Environmental Management, Vol. 52, Issue 5, 2013, pp 1057-1070 associated with minimization of damage to residual stands; a point emphasized, possible investment in finding uses for currently non-merchantable species, and accelerated growth of merchantable species in managed stands.

With SFM, non-timber products and ecological services may also be exploited, e.g. through carbon trades, bio-prospecting, debt-fornature swaps etc. Social uses of forest may also be taken into account (indigenous peoples). Thus SFM is: 'management of primary or secondary forests for the sustained production of timber or other products or both in which forest cover is maintained indefinitely.

\section{Sustainable Forest Management}

The concept of sustainable forest management (SFM) requires forest resource managers to monitor and collect information pertaining to their environmental, economic and social impact. There are increasing expectations from a variety of publics (government, customers, and other stakeholders) that forests be demonstrably well-managed, creating incentives for forest managers to design credible systems for assessing their management performance. It is against this background that local, national and international approaches to regulating forest practices have been evolving. This article reviews the different dimensions of governance as they relate to monitoring and information reporting in the forest sector. Specifically, it discusses the changing role of sovereignnty, the effects of globalization and the emergence of civil society stakeholders in forestry-related decision-making. Concepts such as sovereignty and globalization have important implications for monitoring forest practices and for defining SFM. Whether SFM standard creation and enforcement involves a sovereign, shared-sovereignty or civil society approach will affect the level and nature of SFM monitoring. As a result, we need to better consider the concept of monitoring appropriate to the scale and intensity of operations, how monitoring and information reporting standards differ between jurisdictions, and what this means for 
independently verifying SFM at an inter-jurisdictional level. ${ }^{14}$

Sustainable Forest Management is the management of forests according to the principles of sustainable development. Sustainable forest management uses very broad social, economic and environmental goals. A range of forestry institution now practice various forms of sustainable forest management and a broad range of methods and fools are available that have been tested over time.

The "Forest Principles" adopted at the United Nation Conference on Environmental and Development in Rio de Janeiro in 1992 captured the general international understanding of sustainable forest management at that time. A number of sets of criteria and indicators have since been developed to evaluate the achievement of SFM at both the country and management unit level. These were all attempts to codify and provide for independent assessment of the degree to which the broader objectives of sustainable forest management are being achieved in practice. In 2007, the United Nations General assembly adopted the Non-Legally Binding Instrument on All types of Forests. The instrument was the first of its kind, and reflected the strong international commitment to promote implementation of sustainable forest management through a new approach that brings all stakeholders together. ${ }^{15}$

Criteria and indicators are tools which can be used to conceptualize, evaluate and implement sustainable forest management. Criteria define and characterize the essential elements, as well as a set of conditions or processses, by which sustainable forest management may be assessed. Periodically measured indicators reveal the direction of change with respect to each criterion.

14 Gordon M. Hickey, John L. Innes, "Monitoring Sustainable Forest Management in Different Jurisdictions", Journal Environmental Monitoring and Assessment, Vol. 108, Issue 1-3, 2005, pp 241-260

15 Massimiliano Montini, 2008, Sustainable Development within the Climate Change Regime, in Sustainable Development in International and National Law, edited by Hans Christian Bugge \& Christiana Voight, Groningen: Europe law Publishing, p. 525
Criteria and indicators of sustainable forest management are widely used and many countries produce national reports that assess their progress toward sustainable forest management. There are nine international and regionnal criteria and indicators initiatives, which collectively involve more than 150 countries. Three of the more advanced initiatives are those of the Working Group on Criteria and Indicators for the Conservation and Sustainable Management of Temperate and Boreal Forests (also called the Montreal Process), the Ministerial Conference for the Protection of Forests in Europe, and the International Tropical Timber Organizational. Countries who are members of the initiatives usually agree to produce reports at the same time and using the same indicators. Within countries, at the management unit level, efforts have also been directed at developing local level criteria and indicators of sustainable forest management. The Center for International Forestry Research, the International Model Forest Network and researchers at the University of British Columbia has developed a number of tools and techniques to help forest-dependent communities develop their own local level criteria and indicators. Criteria and Indicators also form the basis of third-party forest certification programs such as the Canadian Standards Association's Sustainable Forest Management Standards and the Sustainable Forestry Initiative Standards.

There appears to be growing international consensus on the key elements of sustainable forest management. Seven common thematic areas of sustainable forest management have emerged based on the criteria of the nine ongoing regional and international criteria and indicators initiatives. The seven thematic areas are: extent of forest resources; biological diversity; forest health and vitality; productive functions and forest resources; protective functions of forest resources; socio-economic functions; and legal, policy and institutional framework

This consensus on common thematic areas (or criteria) effectively provides a common, implicit definition of sustainable forest mana- 
gement. The seven thematic areas were acknowledged by the international forest community at the fourth session of the United Nations Forum on Forests and the $16^{\text {th }}$ session of the Committee on Forestry. These thematic areas have since been enshrined in the Non-Legally Binding Instrument on All Types of Forests as a reference framework for sustainable forest management to help achieve the purpose of the instrument.

\section{Relation between Forest and Economic}

There is often a gradual transition from the collection of 'wild' products in natural forests to enrichment planting in secondary forest and intensively managed home gardens. Reviewing the history of forest manipulation by indigenous people and various types of indigenous forest management, concludes that there is an evolutionary continuum in forest-people interactions, during which a process of co-domestication of forests and trees takes place. Consequently, the natural ecosystem is gradually transformed into an agro-ecosystem. This evolution is characterized by increasing input of human labor per unit of forest land and intensified human intervention in the reproductive biology of desired species. ${ }^{16}$

The rate of deforestation is unpredictable, because no one provided adequate information in estimating the extent of forest cover FAO in 1990 estimates that deforestation in Indonesia about 1.3 million hectares per year, whereas the World Bank in 1990 a rate of 0.9 million per hectares. By adjusting the estimates on this basis, the study derives an alternative deforestation rate of 0.6 million hectares per year. ${ }^{17}$ Lack of action on cross-border environmental problems in developing countries is often ascribed to gaps in local capacity and resources, failure of regional cooperation and lack of financial support from rich countries ${ }^{18}$.

16 M.A.F. Ros-Tonen, "The Role of non-timber forest products in sustainable tropical forest management", Journal Holz als Roh-und Werkstoff, Vol. 58, Issue 3, 2000, pp 196-201

17 Food and Agriculture Organization, 2001

18 Luca Tacconi, Frank Jotzo, R. Quentin Grafton, “Local causes, regional co-operation and global financing for
It is impossible to separate the economy from natural resources and the environment. It is difficult to determine whether natural resources and the environment are part of the economy or conversely whether the economy is an element within natural resources and the environment in their daily activities. People as well as other organism; interact with the nature and the environment in their daily activities. A national account requires to link natural resources and environmental dimension to economic dimensions, by treating the economy as part of the environmental accounting system, rather than carrying out an economic calculation of the environment. Environmental accounting could be used in the future to step up and monitor the maintenance of more effective environmental and resource utilization, so that the desired balance between environmental and economic objectives could be attained.

Natural resources and environmental accounting includes the calculation of all natural resources and environment, both used and not used in the production process. Natural resources and environmental accounting includes the calculation of stock reserve and natural changes of assets that have economic value. In gaining a clear illustration of the economic purpose of natural resources accounting, especially in its relationship to economic policy formulation and development planning, both monetary and physical accounting must be conducted. Due to the difficulties in finding a unit of measurement for all sectors or types of natural resources, the compilation of natural resources that are considered important and strategic.

Bartelmus in 1991 stated the system for integrated Environmental and Economic Accounting (SEEA) developed by the United $\mathrm{Na}$ tions Statistical office includes four points. First, an economic is system of National Account (SNA) which is closely linked to environmental aspects to show the monetary flow, and assets related to the natural environment. Se-

environmental problems: the case of Southeast Asian Haze pollution", Journal International Environmental Agrement: Politic, Law and Economics, Volume 8, Issue 1, 2008, pp 1-16 
cond, valuation of environmental use. Third, physical data concerning the flow of natural resources and environmental foods into the economy, as well as, the waste flow of economic activity to the environmental. Fourth, to describe natural resources and environmental as accurately as possible to evaluate their utilization impact on the economy.

\section{Sustainable Forest Management in Indonesia Forest law (Policy and Institutional Frame- work)}

On the frontispiece of Rachel Carson's 1962 epoch-making book, Silent Spring, we find the following quotation from Albert Schweitzer: "Man has lost the capacity to forestall and foresee. He will end by destroying the earth. ${ }^{19}$ Traditionally, enforcement of environmental law focuses on the use of administrative procedures. Other instruments such as civil environmental liability (in the sense of private party litigation), criminal prosecution, and provision of participatory rights in administrative procedure are classified as secondary, supportive instruments. ${ }^{20}$ The environmental revolution that began in the late 1960s for the developed world refocused the economists' microscope. Air and water quality, pollution, and related concepts of externalities and public goods cap-tured the attention of the discipline.

Forest certification is a mechanism involving the regulation of trade of forest products in order to protect forest resources and improve forest management. Although China had a late start in adopting this process, the country has made good progress in recent years. As of July 31, 2009, 17 forest management enterprises and more than one million hectares of forests in China have been certified by the Forest Stewardship Council (FSC). ${ }^{21}$

19 Bruce Yandle, "Public Choice at the Intersection of Environmental Law and Economics", European Journal law and Economic, Vol. 8, Issue 1, 1999, pp 5-27

20 Christine Godt, "Enforcement of Environmental Law by Individuals and Interest Groups: Reconceptualizing Standing”, Journal of Consumer Policy, Vol. 23, Issue 1, 2000, pp 79-105

21 Jingzhu zhao, Dongming Xie, Danyin Wang, Hongbing Oeng, "Current Status and Problems in Certification of Sustainable Forest Management in China", Journal Envi-
Because of the insignificant volume of forestry insurance business, insurers have commissioned no formal research work. Plantation fire loss data are a sensitive commercial issue and, while studied, are rarely published. Therefore data have been collected from companies making insurance applications as well as during on-site surveys; for this reason data are imperfect as companies rarely keep adequate records of fire losses with respect to either areas affected or actual financial loss. This lack in itself is an extraordinary indictment of the attitude to production that would be unthankable in any other industrial production process. ${ }^{22}$

Most important in the implementation of Sustainable Development is access to information and public participation. It prepares citizens to become decision-makers, offering basic to stimulate creative solutions to social problems and the development environment, and provides a basis for building consensus on important priorities. Governments and agencies governed by transparency, openness, accountability and public participation are better able to reconcile the needs of present and future generations, balancing private and public interests, and align economic development with social and environmental needs. Thus, increased access to information and participation in decision-making will be more likely to lead to sustainable development occurs. ${ }^{23}$

The successful socio-economic development and environmental protection can be reached if we can place the price resources as an integrated unit of social, economic, and environment. Ideally, we should integrate the view points of three disciplines. First, economist, maximize human welfare within constrain of existing capital stock and technologies; second,

ronmental Management, Vol. 48, Issue 6, 2011, pp 1086-1094

22 Phil Cottle, "Insuring Southeast Asian Commercial Forests: Fire risk analysis and the Potential for Use of data in risk pricing and reduction of forest fire risk", Journal Mitigation and Adaptation Strategies for Global Change, Vol. 12, Issue 1, 2007, pp 181-201

23 Sri Wahyuni, 2012, The Concept of Sustainable Development in Indonesia's Forest Law, Post-Doc Thesis, Belgium: Vrije Universiteit Brussels 
ecologist or environmentalist, preserve the integrity of ecological and overall resilience of global ecosystem; and third, sociologist put human being as the key factor.

Economic growth is very closely related to the availability of natural resources. The more rapid the economic growth, the more goods and services are required to fulfill human needs, so those activities will reduce the availability of natural resources. To compensate very rapid development, appropriate management of natural resources and the environment should be implemented. Therefore, economic development has to be environmentally sound in terms of sustainable function and availability of natural resources and the environment, as well as increasing utilization of renewable resources to substitute the function of non renewable resources.

Forest as a national development capital has tangible benefits to the lives and livelihood of the Indonesian Nation, whether the benefits of ecological, cultural or economic, in a balanced and dynamic. For the forests must be maintained and managed, protected and used sustainably for both the public well-being of present and future. Forest management is not just specifies the forest as soil protection, climate, water resources and demand for wood products. However, forest management should be directed to utilize all the land in the interest of the State, and even other countries as well. Thus, it will be understood about the function hydrologic, biologic buffers, and soil fertility, economic, social, cultural, recreation and aesthetic of the forest as a whole. ${ }^{24}$

In this position as one of the determinants of life supporting systems, the forest has provided great benefits to mankind, therefore, must be preserved. Forests have a role as a counterweight and global environment, so its association with the international community is essential to continue prioritizing the national interest.

As logical consequences of the importance of securing the protection of forests will re- quire national and regional policy as a legal umbrella that can be used as guidance and reference in the management of forest resources in accordance with the constitutional mandate set forth in the 1945 Constitution. Article 33 paragraphs (3) of the Constitution of 1945 states "The earth and water and natural resources contained therein is controlled by the State and utilized for the greatest prosperity of the people. Understanding ruled not owned, but a sense of obligation and authority contained in public law.

State rights in the field of forestry are authorized to: ${ }^{25}$ first, establish and regulate the planning, allocation, provision and use of forests in accordance with its function in providing benefits to the people and the State; second, set the forest administration in the broad sense; and third, determine and regulate legal relations person or legal entity to manage the forest legal actions and forests.

In relation to forest resources and management, the preceding analysis suggested that under current financial conditions, the incentives for good forest management and/or reforestation by the private sector are insignificant. Therefore, without government intervention, forest depletion as a result of logging will continue. Fundamental problems are related to an under-pricing of forest resources and weak management of the sector.

Specific factors that influence the implementation of environmental law are as follows: the unfinished boundary, lack of quality and quantity of power, ownership and encroachment, inconsistent land use designation, the existence of settlements in the region, uncontrolled logging or timber theft, danger fire, overlapping with plantations, weak oversight of access roads throughout the region, and the lack of coordination between relevant agencies. Local governments need to improve coordination system for each of the relevant agen-

25 Constitutional of Indonesia 1945

24 Forestry Law No. 41 Year 1999 
cies to implement the protection and conservation of forests. ${ }^{26}$

Indonesia, as an example, this review shows how narratives of change and complexity linking the subsistence agroecological practices of upland communities, deforestation, and biodiversity loss, and the policy interventions that result, emerge within several institutionalized and embedded perspectives, including (a) an entrenched political and administrative discourse on modernization and development in Indonesia, (b) a subsequent emphasis on the culturalization or civilization of upland groups considered backward or primitive, and (c) linear or equilibrium explanations of upland change linking population growth and environmental decline. ${ }^{27}$

Development (development) is the application of human, financial, and physical resources to satisfy human needs and improve the quality of life. ${ }^{28}$ Development is a demand of human resources, financial and natural resources to satisfy human needs and improve the quality of life. Paradigm adopted for this development is always associated with growth (economic), as a dream of developmentalism. This paradigm is still the benchmark, not only in the course of the Stockholm Conference on the Environment in 1972, but also as part of the compromise attitude developmentalism with environmentalism at the Earth Summit in Rio de Janeiro.

With increasing population pressure and the need for continuing growth in employment and exports, a number of issues have emerged in the management of Indonesia's forests that includes: first, the rate of deforestation; second, the sustainable management of the production forest; third, the welfare of forest dwelling communities; and fourth, as accura-

26 Sri Wahyuni, 2007, Rechtprbleme der Tropenwaldbewirtschaftung in Indonesien, Germany, WVD, Berlin: Universiteit Bremen, p. 50

27 Derek Armitage, "Nature-Society Dynamics, Policy Narratives, and Ecosystem Management: Integrating Perspectives On Upland Change and Complexity in Central Sulawesi”, Indonesia, Journal Ecosystem, Vol. \&, Issue 7, 2004, pp 717-728

28 Butterworths Concise Australian Legal Dictionary, Second Edition, Sydney-Perth, 1998 tely as possible to evaluate their utilization impact on the economy.

During the seventies, Indonesia was the largest exporter of tropical timber in the construction world and sent nearly 300 million cubic meters to world markets. Influenced by the growth in the domestic wood processing, the government declared the mid-80s, a national ban on exports to generate economic investment in further processing stages in the production of wood veneer. At the end of this decade, Indonesia had 132 plywood products, who were capable of a production of over 12 million square meters per year Veneers. Indonesia's wood-based panels industry delivered during the nineties, over 70 percent of tropical plywood exports in the world and generated an average of $\$ 3.5$ billion annual export income ${ }^{29}$.

One of the significant initiatives for achieving sustainable forest management is the development of criteria and indicators (C\&l). This initiative was originally conceived through the Forest Principles and Chapter 11 of Agenda 21 of the Rio Declaration on Environment and Development. Included in these principles is the identification of C\&l for evaluating the practice of sustainable management. Consequently, this led to a number of initiatives at the national, regional, and international levels (e.g., The Helsinki Process, The Montreal Process, The Amazon Cooperation Treaty: Tarapoto). Several expert meetings have been convened for the purpose of developing $C \&$ l both at the national and international levels (e.g., FAO/ITTO Expert Meeting on the harmonization of Criteria and Indicators; FAO/CCAD: Comision Centroamericano de Ambiente y Desarollo Expert Meeting on Criteria and Indicators for sustainable management in Central America, Teg ucigalpa, Honduras, January 1997; UNEP/FAO Expert Meeting on Criteria and Indicators for sustainable management in Dry-Zone Africa) ${ }^{30}$.

29 Sri Wahyuni, "The Concept of Sustainable Development in Indonesian's Forest law (Case Study: Tesso Nilo's National Park in Pelalawan Regency, Riau Province, Indonesia)", International Journal on Environment and Rural Development, Vol. 2, Issue 2 2011, p 55

30 Gordon M. Hickey, John L. Innes, "Monitoring Sustainable Forest Management in Different Jurisdictions", 
C\&l can be viewed as tools that can be used to collect and organize information in a manner that is useful in conceptualizing, evaluating, implementing, and communicating sustainnable forest management. These $C \& \mid$ are envisioned to be used for a variety of purposes including; (1) monitoring forest management, (2) accrediting or certifying forest industries with respect to how well they are managing their forests, (3) serving as a guide to forest managers in order to help them achieve better management of their forests, and (4) aiding forest institutions in marshaling their resources by targeting areas that are most in need of remediation. Protection of forests according to Forestry Law No. 41 year 1999, Article 46 states: "Forest protection and nature conservation aimed at keeping the forest, forest area and its environment. So that protection, conservation functions and production functions, is achieved in an optimal and sustainable". Sustainable Forest Management (SFM) requires information on plant growth and nutrient dynamics in forest ecosystems. ${ }^{31}$

From the article mentioned above confirms that the implementation of forest protection functions are intended to preserve the conservation of forests in order to remain sustainable, and are concerned with the conservation of natural resources and its ecosystem is set according to statutory provisions. Article 47 confirms that the protection of forests and forest areas is an attempt to: (2) to prevent and limit the damage to forests, forest areas, and forest products caused by human actions, livestock, fire, natural hazards and disease pests, and (3) maintain and safeguard the right of nations, communities and individuals over.

According to Government Regulation Number 45 of 2004 Article 1 Paragraph (1): "Forest protection is an attempt to prevent and limit the damage to forests, forest area and forest products, which are caused by human

Journal Environmental Monitoring and Assessment, Vol. 108, Issue 1-3, 2005, pp 241-260

31 Cahyono Agus (eds.), "Sustainable site productivity and nutrient management in a sort rotation plantation of Gmelina Arborea in East Kalimantan, Indonesia", Journal New Forest, Vol. 28, Issue 2-3, 2004, pp 277-285 actions, livestock, fire, natural hazards, pests and diseases, as well as and safeguards the right of nations, communities and individuals over forest, forest area, forest products, investment and instrument related to forest.

Forest as part national natural resources has a meaning and an important role in various aspects of social life, development and environment has been accepted as an international agreement, that the forest is an important function for the life of the world. Forests have benefits for life the forest is assured of its existence so that can function.

Forests not only as natural resources that support economic development, but also as a natural resource that support the preservation of cultural and social environment. Environmental damage is due to the activity of human activities that cause disruption to the ecosystem of the environment, causing changes in physical properties of biological of life, so that the reduced function of this environment. It can occur as a result of illegal logging are result of forest to barren, so wait for the function of forests as watersheds and also cause erosion.

Therefore, awareness of environmental law is needed by all stakeholders, including government, private sector and the community, whether its conservation and management, in essence people should have a high awareness of the law, because humans have a biological or sociological relationship is directly with the environment in which he be, since he was born until death. But awareness of the laws still influenced by several factors, such as economic, and cultural and others. Therefore, the need for strategic efforts to raise awareness that law, both in terms of human mental and terms of the policy. Synergies are both important, because the awareness that there is a growing law because it is in accordance with the values espoused. For example, people who like the clean life, then he wills no litter. Legal awareness can also grow because of fear of the sanc- 
tions imposed. This false consciousness that many are owned by the community. ${ }^{32}$

Regardless of the cause of legal awareness is emerging, which is dangerous if it has no awareness of the law but then decreased even lost to external factors, such as law enforcement is not strict and selective logging. This would lower the legal consciousness of society and cause public mistrust of the law. Thus, efforts to foster awareness of the law are not enough to prosecute people, but also must be accompanied by models and law enforcement. Humans, both his position as a member of the community, as entrepreneurs, as law enforcement officers, as well as the makers/decision makers, must have the awareness of environmental law although gradually, from just knowing to obey and respect the various provisions of existing environmental laws. ${ }^{33}$

Recognizing the importance of forest resource management arrangements on an ongoing basis, as an umbrella law and guidelines for the management of forest resources and for securing the protection of forest, the government has issued Law No. 5 of 1967 on basic provisions forestry and government regulation No. 28 of 1985 on Forest Protection, which is then updated with Law Number 41 Year 1999 on Forestry.

As an elaboration of the Forestry Law no. 41 of 1999, the government also has issued Government Regulation No. 34 of 2002 regarding the Law and Forest Management Planning, Forest Utilization and Use of Forest, Government Regulation No. 35 of 2002 on the Reforestation Fund, Government Regulation No 44 Year 2004 on Forestry Planning and Government Regulation Number 45 year 2004 on the Protection of Forests.

In the Forestry Law No, 41 year 1999, Article 47 states that: The protection of forests and forest areas is an attempt to: first, prevent

32 Sri Wahyuni, "Sustainable Development in Indonesian Environmental Law, Lesson from Germany's Sustainable Forst Management Practises", International Journal on Environmental and Rural Development, Vol. 2, Issue 2, 2013, p. 35

33 Sri Wahyuni, Dissertation, loc.cit. p. 75 and limit damage to forests, forest areas, and forest products caused by; second, human actions, livestock, fire, natural hazards, pests and diseases; and third, maintain and safeguards the rights of the State, society, and individuals over the forest, forest area, forest products, investments and instruments pertaining to forest management.

According to Government Regulation No. 28 of 1985 juncto Government Regulation Number 45 of 2004 states that: "Forest protection is an attempt to prevent and limit the damage to forests, forest area and forest products, which are caused by human actions, livestock, fire, natural hazards, pests and diseases, and to defend and safeguard the rights of the State, communities and individuals over the forest, forest area, forest products, investment and instruments related to forest management".

The purpose of forest Protection, as mentioned in Article (5) Government Regulation Number 45 Year 2004 is: forest protection aims to preserve forests, forest products, forest area and its environment, so that protection, conservation functions and production functions, is achieved in an optimal and sustainable. While the principles of forest protection are listed in clause (6) include: first, prevent and limit damage to forests, forest areas, and forest products caused by human actions, livestock, fire, natural hazards, pests and diseases; and second, maintain and safeguards the rights of the State, communities and individuals over the forest, forest area, forest products, investments and instruments pertaining to forests management.

With the implementation of Forestry Law Number 22 Year 1999 regarding Regional Government, which was then in the revision by Act No. 32 of 2004, the local government or local communities have a greater opportunity to participate in the management of forest resources and forest protection following security and law enforcement. This means that people have not only rights but also obligations required.

The existence of this decision is a positive step as a follow-up mandate of Law Number 
41 year 1999 on Forestry. The policy should be followed by concrete measures of surveillance and increase enforcement in the forestry sector, in order to issue policies on forest protecttion as set forth in Forestry Law Number 41 year 1999 can be complied with and implemented by the Government and local law enforcement agencies with the group community groups, meaning that people should be empowered in such a way as well as responsible for the implementation of conservation and protection of forests so that the implementation of any policy on the management of forest resources and forest protection law enforcement can work well. Because one factor among others, due to weak controls have not been coordinated surveillance and law enforcement field, besides that it is still low awareness of the legal community itself.

With the issuance of Forestry Law Number 41 year 1999 regarding Forestry then followed up by the Government No. 34 of 2002 on Forest and Forest Management, Forest Utilization and Use of Forest, Government Regulation Number 44 Year 2004 on Forest Planning. But the reality to date, forest encroachment, forest fire, illegal logging, illegal land still held in nearly all the country site, the Sate forest encroachment by a group of both the immigrant community which makes oil palm plantations, forest and land fires almost every years during the dry season occurs. And that became the central and crucial issue is illegal logging and illegal land continues.

Illegal logging activity practically reached dangerous levels, in additional to decreasing quality of environmental diversity, and resulted in a national forest degradation and loss of biodiversity conservation. Besides, the right of the State as forest concessions that have been felled there is no input to the State, and weakening the integrity of corrupt officials. Various factors driving the occurrence of illegal logging include: timber demand continues to increase; geographic conditions of Riau Province; lack of supervision and coordination; availability of dark market; and community sector social conditions are still poor and unemployed.
According to Article 2 of Forestry Law No. 41 year 1999 sates: Forest governance based on principles of benefit and sustainability, democracy and justice, togetherness, openness and integrity. Forest governance and sustainable benefits, meant that any implementation of forestry administration attention to the balance and sustainability elements of the environment, social and cultural as well as economic.

Forest governance based on populist and justice meant that each of forestry administration should provide opportunities and equal opportunities to all citizens according to his ability, so as to increase the prosperity of all people. Forest governance together, are intended to apply the pattern in the organization of forestry joint venture so interwoven interconnectedness and interdependence in synergy between local communities and state enterprises, in order to empower small and medium enterprises and cooperatives. Forest governance disclosure, are intended to include any activity of forestry administration and the aspirations of the community.

Integration of forestry administration meant that every forestry operation conducted in an integrated manner with due regard to national interest, other sectors and local communities. The purpose of forestry administration listed in Article of Forestry Law No. 41 year 1999 which states that the implementation of forestry aims for the greatest welfare of the people a just and sustainable by: first. Guarantee the existence of the forest with an area of considerable and proportional distribution; second, optimizing the variety of functions which includes functions forest, protection forest and production functions to achieve the environmental, social, cultural and economic balance and sustainable; third, increasing the carrying capacity of the watershed; fourth, increasing capacity to develop and empowerment through participatory, equitable, and environmentally friendly so as to create social and economic resilience and resistance to external change; and fifth, ensuring equitable distribution of benefits and sustainable. 
There are three elements contained in the formulation of forest law, namely: the rules of forest law, whether written or unwritten; set the relationship between the State with forests and forestry; and set the relationship between individuals with forests and forestry. Countries in the field of forestry right as set forth in article 4 of Forestry Law no. 41 year 1999 are authorized to:

1. All forests within the territory of the Republic of Indonesia, including the natural riches contained therein are controlled by the State for the greatest prosperity of the people.

2. Forest control by the State as referred to in paragraph (1) authorized the Government to:

a. Set up and take care of everything related to the forest, forest and forest products

b. Determine the status of certain areas as forest or non forest area.

c. Organize and establish legal relations between the people and the forest and regulate the legal actions concerning forestry.

3. Forest control by the State shall respect the customary la, as long as it exists and its existence is recognized and does not conflict with national interests.

In article 10 of Forestry Law no. 41 year 1999 on forestry on forest administration set. A Forest management objective is to obtain maximum benefits as well as versatile and sustainable prosperity for the people. Management of forests as referred to above include the implementation of activities, namely: planning of forestry; forest management; research and development, education and training and forestry extension; and supervision.

In essence the purpose of forest administration in the broad sense is to achieve the benefits of forests as much as possible, a multipurpose and sustainable, either directly or indirectly in order to build a just and prosperous society. Activities administered by the State in the forestry sector include: first, organize and implement the protection, strengthening, structuring, development and exploitation of forests and reforestation; second, taking care of forests and forest preserve and nurture wildlife tours and hunting; third, conduct an inventory of the forest; and fourth, conducting research on forests and forest products and benefits, as well as socio-economic research the people who live in and around the forest.

In article 11 of Forestry Law No. 41 year 1999 stated that:

1. Forestry planning is intended to provide guidance and direction to ensure the achievement of the objectives of forestry

2. Forestry planning undertaken in a transparent, accountable, participatory, integrated and attention to specifics and regional aspirations.

Forestry planning according to Article 1 paragraph (1) Government 44 of 2004 on Forestry planning is a process of goal setting, determination and devices required activities in sustainable forest management to provide guidance and direction, to ensure the achievement of the objectives of forestry for the greatest welfare of the people a just and sustainable. Article 2 asserts as follows:

1. The purpose of forest planning is to provide guidance and direction for the government, provincial, district/city governments, community, entrepreneurs, professional institution, which includes forestry strategies and policies to ensure the achievement of the objectives of forestry.

2. Forestry planning objectives is to realize the implementation of effective and efficient forestry to achieve optimum benefit functions of forests and sustainable.

Guidance and direction to realize the goal of planning formulated in the form of a vision, mission and strategy that serves as toll to achieve optimization of the utilization of forest area. Article 12 of Forestry Law no. 41 year 1999 asserted that Forest Plan includes: forest inventory; inauguration of the forest area; forest stewardship; establishment of forest management area; and the preparation of forestry plans

In the administration of government and state in each State, the principle of legality is 
one of the main principle on which the State especially for law countries in continental systems. The principle of legality became the basis of legitimacy of government action and guarantees the protection of the rights of the people. The principle of legality means that efforts to achieve integral harmony duet between understanding and understands the rule of law based on the principle of popular sovereignty mono dualistic as the pillars, which constitutively essential character. Other authorities of the State in field of forestry are to regulate the legal relationship between the subject of law and the forest, and the deeds of the forest.

In article 4 of Forestry Law Year 1999 mentioned about the rights of the principle of State forest. In the article was prescribed all the forests in the territory of the Republic of Indonesia including natural riches contained therein is controlled by the State for the greatest prosperity of the people. The purpose of forest by the State is authorized the Government to: set up and take care of everything related to the forest, forest, and forest products; determine the status of certain areas as forest or non forest area; and rrganize and establish legal relation between the people and the forest and regulate the legal actions concerning forestry.

\section{Conclusion}

Sustainable forest management is discussed within the historical and theoretical framework of the sustainable development debate. The various criteria and indicators for sustainable forest management put forth by different institutions are critically explored. Sustainable Forest Management does not necessarily imply constant or smooth flow of goods and services. The main concern of a sustainable system is to ensure that there is no major sustained imbalance in demand and supply for the goods and services. Regardless of the cause of legal awareness is emerging, which is dangerous if it has no awareness of the law but then decreased even lost to external factors, such as law enforcement is not strict and selective logging. This would lower the legal consciousness of society and cause public mistrust of the law. Thus, efforts to foster awareness of the law are not enough to prosecute people, but also must be accompanied by models and law enforcement. Humans, both his position as a member of the community, as entrepreneurs, as law enforcement officers, as well as the makers/decision makers, must have the awareness of environmenttal law although gradually, from just knowing to obey and respect the various provisions of existing environmental laws.

\section{Bibliography}

Agus, Cahyono (eds.). "Sustainable site productivity and nutrient management in a sort rotation plantation of Gmelina Arborea in East Kalimantan, Indonesia". Journal New Forest, 2004, Vol. 28, Issue 2-3

Anderson, William L \& Daniel A Mizak. "Politics of Environmental Law: Political Ideology, Elitism or Urban-Rural Interest?". Journal Public Choice, Vol. 129, Issue 1-2, 2006;

Anon. 1995. Criteria and Indicator for the Conservation and Sustainable Management of Temperate and Boreal Forests. Ottawa: The Montreal Process, Canadian Forest Service;

Arcuri, Alessandra. "A different Reason for "De-Coasing" Environmental Law and Economics". Journal European Journal of Law and Economics, Vol. 20, Issue 2, 2005;

Armitage, Derek. "Nature-Society Dynamics, Policy Narratives, and Ecosystem Management: Integrating Perspectives On Upland Change and Complexity in Central Sulawesi, Indonesia". Journal Ecosystem, Vol. \&, Issue 7, 2004;

Brundtland Report. 1987. Report of the World Commission for Environment and Development, Our Common Future, Oxford: OUP;

Butterworths Concise Australian Legal Dictionary, Second Edition, Sydney-Perth, 1998

Cottle, Phil. "Insuring Southeast Asian Commercial Forests: Fire risk analysis and the Potential for Use of data in risk pricing and reduction of forest fire risk". Journal Mitigation and Adaptation Strategies for Global Change, Vol. 12, Issue 1, 2007; 
Djamhuri, Tri Lestari. "Community Participation in a social Forestry program in Central java, Indonesia: The Effect of incentive structure and social capital". Journal Agroforestry System, Vol. 74, Issue 1. 2008;

Eve, Evaldice. Fransisca A Arguelles, Phillip M. Fearnside. "How much do Brazils's Environmental Law work in practice? Environmental Impact Assessment and the case of the Itapiranga Private Sustainable Logging Plan". Journal Environmental Management, Vol. 26, Issue 3, 2000;

Food \& Agricultural Organization (FAO). 1993a. Forest Resources Assessment 1990, Tropical Countries. Forestry paper No. 112 Rome;

Forslind, K. Helen. "The Economics of Environmental Law Enforcement: end-of-life Vehicles". Journal European Journal of Law and Economics, Vol. 23, Issue 3, 2007;

Godt, Christine. "Enforcement of Environmental Law by Individuals and Interest Groups: Reconceptualizing Standing". Journal of Consumer Policy, Vol. 23, Issue 1, 2000;

Hall, J-Peter. "Criteria and Indicators of Sustainable Forest Management". Journal Environmental and Monitoring and Assessment, Volume 67, Issue 1-2, 2001;

Hickey, Gordon M. \& John L. Innes. “Monitoring Sustainable Forest Management in Different Jurisdictions". Journal Environmental Monitoring and Assessment, Vol. 108, Issue 1-3, 2005;

Kaya, M., L. Kammesheidt, H.-J. Weidest. "The Forest garden system of Saparna Island Central Maluku, Indonesia, and its role in Maintaining free species diversity". Journal Agroforestry Systems, Vol. 54, Issue 3, 2002;

Kim, Rakhyun E. and Brendan Mackey. International Environmental law as a complex adaptic system". Journal International Environmental Agreements, Politics, Law and Economics, Vol. 14, issue 1, 2014;

Lebel, Louis. Antonio Contras. "Suparb Pasong, Po Garden, No Body Knows Best: Alternative Perspectives on Forest Management and Governance in Southeast Asia". Journal International Environmental Agreement, Vol. 4, Issue 2, 2004;

Markundi, Willy R. "Global Climate Change Mitigation and Sustainable Forest Management-The Challenge Monitoring and Veri- fication". Journal Mitigation and Adaptation Strategies for Global Change, Vol. 2, issue 2-3, 1997;

Middleton, Beth Rose. "Just Another hoop to jump through? Using Environmental Law and Process to Protect Indigenous Rights". Journal Environmental Management, Vol. 52, Issue 5, 2013;

Mondoza, Guillermo A. and Ravi Prabhu. "Development of a Methodology for Selecting Criteria and Indicators of Sustainability Forest Management: A Case Study on Participatory Assessment". Journal Environmental Management, Vol. 26, Issue 6, 2000;

Montini, Massimiliano. 2008. Sustainable Development within the Climate Change Regime, in Sustainable Development in International and National Law. Edited by Hans Christian Bugge \& Christiana Voight. Groningen: Europe law Publishing;

Obidzinski, Krystof. Ahmad Dermawan, Adi Hadianto. "Oil Plantation Investment in Indonesia's Forest Frontiers: Limited Economic Multipliers and Uncertain benefits for local Communities". Journal Environment, Development and Sustainability, 2014;

Prabhu, Ravi., C. Colfer \& R. G. Dudley. 1998. Guidelines for developing, testing and selecting criteria and indicators for sustainable forest management. CIFOR Special Publication;

Purnomo, Herry. Yurdi Yasmi, Ravi Prabhu, Linda Yuliani, Hari Priyadi, and Jerome $\mathrm{K}$ Vanclay. "Collaborative modeling to support forest management: Qualitative system analysis at Lumut Mountain Indonesia”. Journal Small Scale Forest Economics, Management and Policy, Vol. 2, Issue 2, 2003;

Roe, Emery. "Varieties of Issue in Completeness and Coordination: An Example from Ecosystem Management". Policy Science Journal, Volume 34, Issue 2;

Ros-Tonen, M.A.F. "The Role of non-timber forest products in sustainable tropical forest management". Journal Holz als Rohund Werkstoff, Vol. 58, Issue 3, 2000;

Siahaan, NHT. 2004. Hukum Lingkungan dan Ekologi Pembangunan. Jakarta: Erlangga;

Tacconi, L., P.F. Moore, D. Karmowitz. “Fires in Tropical Forests-what really the problem? Lessons from Indonesia". Journal 
Mitigation and Adaptation Strategies for Global Change, Vol. 12, Issue. 1, 2007;

Tacconi, Luca., Frank Jotzo, R. Quentin Grafton. "Local causes, regional co-operation and global financing for environmental problems: the case of Southeast Asian Haze pollution". Journal International Environmental Agrement: Politic, Law and Economics, Volume 8, Issue 1, 2008;

Wahyuni, Sri. 2007. Rechtprobleme der Tropenwaldbewirtschaftung in Indonesien. Dissertation. Berlin: Universiteit Bremen, Germany, WVD;

. "Sustainable Development in Indonesian Environmental Law, Lesson from Germany's Sustainable Forst Management Practises". International journal on Environmental and Rural Development, Vol. 2, Issue 2, 2013;

. "The Concept of Sustainable Development in Indonesian's Forest law (Case Study: Tesso Nilo's National Park in Pelalawan Regency, Riau Province, Indonesia)". International Journal on Environment and Rural Development, Vol. 2, Issue 2, 2011;

2012. The Concept of Sustainable Development in Indonesia's Forest Law. PostDoc Thesis. Belgium: Vrije Universiteit Brussels;

WCED (World Commission on Environmental Development), 1987, Our Common Future, Oxford: Oxford University Press;

Wiersum, KF. "Forest gardens as an intermediate land-use system in the nature-culture continuum: Characteristics and future potential". Journal Agroforestry Systems, Vol. 61-62, Issue 1-3, 2004;

World Bank. 1992. A strategy for Asia forestry Development. Washington D.C: Asia Technical Department;

Yandle, Bruce. "Public Choice at the Intersection of Environmental Law and Economics", Europena Journal law and Economic, Vol. 8, Issue 1, 1999;

Zhao, Jingzhu. Dongming Xie, Danyin Wang, Hongbing Oeng. "Current Status and Problems in Certification of Sustainable Forest Management in China". Journal Environmental Management, Vol. 48, Issue 6, 2011; 